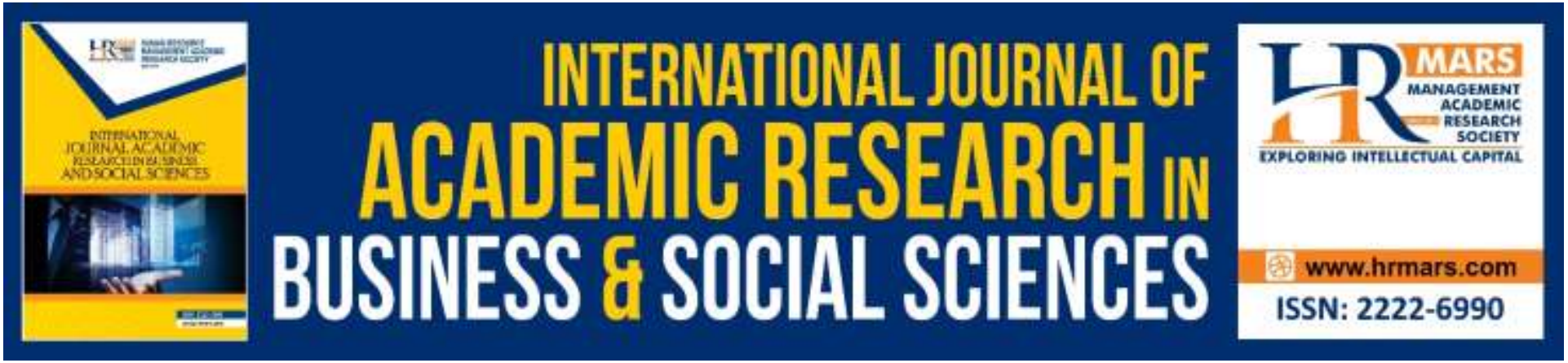

\title{
Scaffolding through Project Based Learning on the Change of Student Achievement: A Study in Accounting Principles Subject
}

Nor Sa'adah Jamaluddin, Suhaida Abd. Kadir, Siti Noormi Alias \& Arnida Abdullah

To Link this Article: http://dx.doi.org/10.6007/IJARBSS/v9-i9/6330

DOI: $10.6007 /$ IJARBSS/v9-i9/6330

Received: 07 July 2019, Revised: 11 August 2019, Accepted: 29 August 2019

Published Online: 19 September 2019

In-Text Citation: (Jamaluddin, Kadir, Alias, \& Abdullah, 2019)

To Cite this Article: Jamaluddin, N. S., Kadir, S. A., Alias, S. N., \& Abdullah, A. (2019). Scaffolding through Project Based Learning on the Change of Student Achievement: A Study in Accounting Principles Subject. International Journal of Academic Research in Business and Social Sciences, 9(9), 567-577.

\section{Copyright: (c) 2019 The Author(s)}

Published by Human Resource Management Academic Research Society (www.hrmars.com)

This article is published under the Creative Commons Attribution (CC BY 4.0) license. Anyone may reproduce, distribute, translate and create derivative works of this article (for both commercial and non-commercial purposes), subject to full attribution to the original publication and authors. The full terms of this license may be seen at: http://creativecommons.org/licences/by/4.0/legalcode

Vol. 9, No. 9, 2019, Pg. 567 - 577

Full Terms \& Conditions of access and use can be found at http://hrmars.com/index.php/pages/detail/publication-ethics 


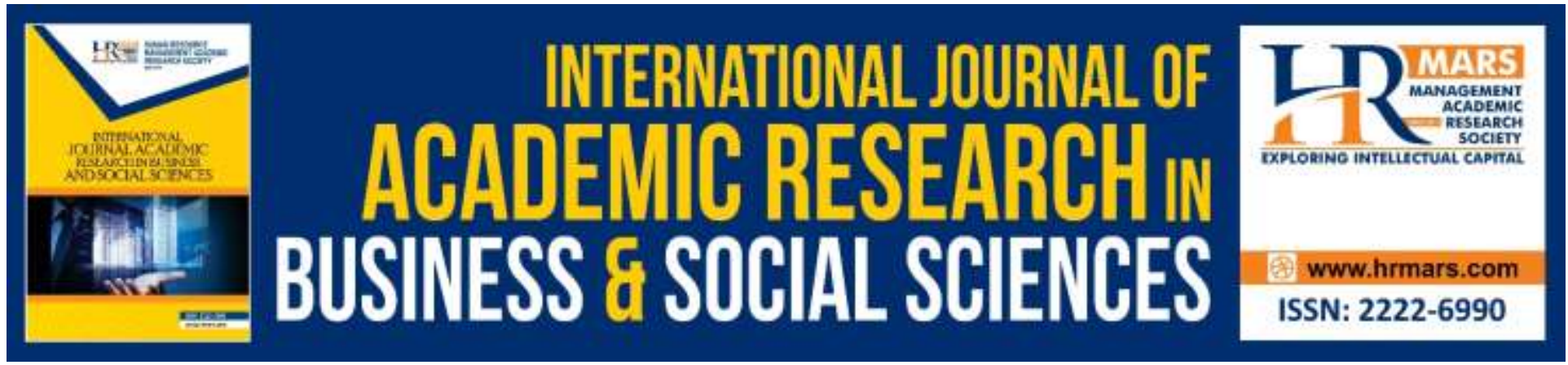

\title{
Scaffolding through Project Based Learning on the Change of Student Achievement: A Study in Accounting Principles Subject
}

\author{
Nor Sa'adah Jamaluddin, Suhaida Abd. Kadir, Siti Noormi Alias \\ \& Arnida Abdullah \\ Faculty of Educational Studies, University Putra Malaysia, Serdang
}

\begin{abstract}
The Project-Based Learning (PBP) is one of the teaching and learning strategies that is often emphasized in teaching and facilitating sessions $(P d P C)$ in schools. In line with the transformation of national education, through the implementation of the Secondary School Standards Curriculum (KSSM), the application of PBP is seen able contribute to produce excellence's students not only in the academic field but to help students master the diversity of 21st century skills. Hence, this study was conducted on Form 4 pupils who took the Elective Subjects (MPEI) of Accounting Principles (PP) by making the topic of Financial Statement of the Sole Proprietorship as a main focus in studying the impact of PBP on the changes of student achievement. The use of specialized modules in the purpose of this study takes involvement of scaffolding elements. The quasi experiemental design was employed with the pre and post group. The sample of this study was 40 respondents from form 4 pupils of private schools in the state of Selangor, representing 20 respondents of treatment group and 20 respondents of control groups. The findings shows the significant difference between the mean score of the treatment group and the control group. This finding illustrates that through the application of PBP with scaffolding, pupils 'achievement in their learning can be improved as well as attesting the application of PBP with scaffolding should be used as one of the alternatives in PdPc sessions in order to ensure students' excellence always consistent.
\end{abstract} Keywords: Project-Based Learning, Scaffolding, Accounting Principles

\section{Introduction}

Accounting Principle Elective Subject or MPEI PP Secondary School Standard Curriculum (SSSC) objective is to produce individuals who are knowledgeable and skilled in accounting as well as have good mastery and excellent in various $21^{\text {st }}$ century skills such as communication, information technology, reflective and critical thinking, and making decision. Besides that, creating individuals who has accountability, practice ethical work culture and practice life-long learning are also being emphasized in MPEI PP's curriculum. 
These are achieved through meaningful learning approach based on unity in theory and practice of accounting which could be applied in one's career and daily life. Suitable with educational transformation that is carried out by the government through Malaysia Educational Development Plan (MEDP) 2013-2025, the government's wish to give birth to individuals who thinks nationally and internationally could be achieved through selection of suitable teaching and learning strategy utilized in schools. Selection of suitable teaching and learning strategy in class could aid the students in mastering various $21^{\text {st }}$ century skills which eventually would increase their marketability (Arshad \& Yasin, 2015).

Integration of values, skills and knowledge is the main focus in enhancing the students' learning performance (Curriculum Development Department, 2016). This integration could be easily achieved through application of suitable teaching and learning strategy such as self-learning, project based learning, inquiry based learning and problem solving (Curriculum Development Department, 2016). Teaching and learning strategy that is suggested in MPEI PP SSSC emphasizes on task-based mastery of knowledge and skills in which the teacher is appointed as facilitator. Hence, active or student-based learning strategy must be practiced by all teachers as a substitute to the traditional passive learning strategy. As a result, the students will be provided with the ability to intertwine previous knowledge with new knowledge through social interaction between teachers, students and the surrounding environment (Ismail \& Othman, 2017). Project based learning that employs constructivism theory as a basis is one of the strategies that fulfil the characteristics of an active learning (Kizkapan \& Bektas, 2017).

\section{Project Based Learning}

Project based learning strategy (PBL) is one of constructivist teaching and learning strategy (Kizkapan \& Bektas, 2017; Frank \& Barzilai, 2004). It is also an alternative that supports educational transformation (Curriculum Development Department, 2016; Guthrie, 2008) and it is suitable to be carried out as a way to supply the students with $21^{\text {st }}$ century skills (See, Mat Rashid \& Bakar, 2015). MEDP (2013-2025) also recommend the teachers to intensify teaching and learning session by ensuring the 6 pillars of SSSC framework which are Communication; Spiritual, Attitude and Values; Humanities; Personal Competence; Physical Development and Aesthetic; as well as Science and Technology are emphasized as the six pillars are the main domain that supports one another, integrated with critical, creative and innovative thinking.

PBL in this research context refers to a model that is built specifically as an enhancement towards classroom activity that is teacher oriented into constructivistoriented teaching that revolves around the students through active classroom activity (Othman \& Osman, 2014) which indirectly integrates with real life issues and practices (Nordin, 2013; Barak \& Shachar, 2008). PBL as seen by past researchers is the best and right platform in cultivating students' high order cognitive skills aside from encouraging meaningful learning (Kizkapan \& Bektas, 2017). Furthermore, it also gives the students with diverse potentials that are integrated and comprehensive (Curriculum Development Department, 2016). Nevertheless, the need for a detailed preparation more or less interferes with the implementation of PBL (Robinson, 2013).

Based on the model that has been designed specifically for this research, teachers are given the role of a facilitator as they have the ability to assist the students in transforming their mind into higher level thinking (McLeod, 2007). Wood, Bruner, and Ross 
(1976) explained that students' mind transformation process that involves the assistance of a teacher is known as scaffolding which refers to proximal zone according to Vygotsky's notion (McLeod, 2007; Vygotsky, 1978).

\section{Scaffolding}

Preparation of various support (Bowles, Radford \& Bakopoulou, 2017) in ensuring the students gain their knowledge through constructivist learning environment is the basic concept of scaffolding that is related to social theory pioneered by Vygotsky (1978). The creation of structural task framework by teachers to observe the students' development in learning proved the importance of support element in teaching and learning session. At the same time, it also proved that project based learning strategy with scaffolding contributes towards students' cognitive development. In order to execute this research, Erdem's 11 level of learning (2012) that was adapted from Moursund model (1999) is used as reference as shown in Table 1. Besides, procedures involved in the execution of PBL are portrayed in Figure 1.

Table 1: Project Based Learning Levels

\begin{tabular}{|c|c|}
\hline Level & Activity \\
\hline 1 & Identify teaching and learning objective \\
\hline 2 & $\begin{array}{l}\text { Identify and determine the problems that are required to be solved by the } \\
\text { students }\end{array}$ \\
\hline 3 & Identify the reporting and presentation format \\
\hline 4 & Identify evaluation criteria \\
\hline 5 & Form groups \\
\hline 6 & Identify directed questions as suggested by the teachers \\
\hline 7 & Plan information gathering process \\
\hline 8 & Plan work schedule \\
\hline 9 & Identify checklist \\
\hline 10 & Gather, organize and repost data \\
\hline 11 & Present result and conclusion \\
\hline
\end{tabular}

Source: Moursund (1999) and Erdem (2012)

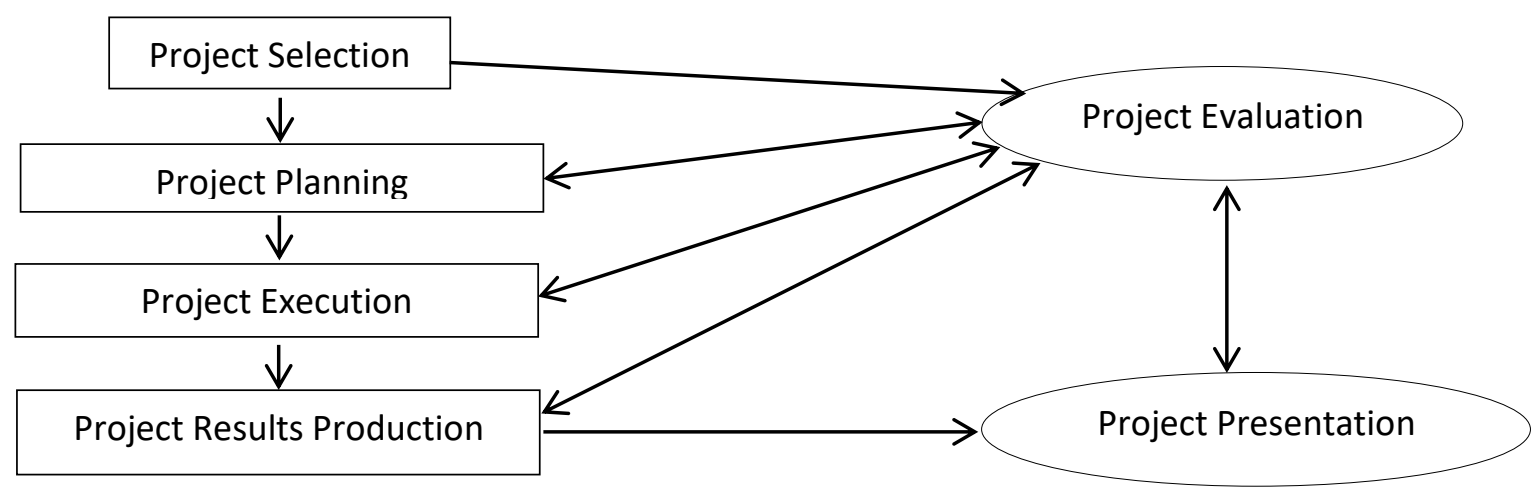

Figure 1: Project Based Learning Module Procedures

(Source: Wu \& Meng, 2010) 


\section{Problem Statement}

Traditional teaching and learning strategy that forbids students active participation in class cause the students to have stunted mind development. Research by Nooriza and Effandi (2015) stated that teacher-oriented learning interrupts with the students' mind transformation thus affecting their academic performance. However, student-oriented learning is able to support the students' mind transformation in terms of cognitive, metacognitive, and affective aspect (Wilkin, 2017).

Our education scenario that is exam-oriented creates weakness in mastering and applying various method and technique in teaching and learning session among teachers thus affecting the students' generic development. This is because excitement in receiving exam result with flying colours cause learning activity to occur atomistically as there is time constraint for the teachers to vary their techniques and method during teaching and learning session (See et al., 2015). The usage of diverse technique and method during teaching and learning session will not only contribute towards excellent achievement but it also provides the students with the required $21^{\text {st }}$ century skills such as communication skill, problem solving skill, and higher order thinking skills (Yusof, 2017; Abosalem, 2016).

This is evidenced by previous studies explaining that PBL strategy with scaffolding applied by teachers during teaching and learning sessions in schools can contribute to the transformation of student mindset and result in improved achievement in learning (Roy, 2018; Salam, Mailok \& Ubaidullah, 2015; See et al., 2015). However, the findings of previous researchers are not comprehensive and only focus on specific subjects (Roy, 2018; Salam et al., 2015; See et al., 2015). Therefore, this study was conducted to contribute to the diversity of existing research findings by focusing the study on the subject of accounting principles for form 4 accounting students. From the findings of this study, the contribution of ideas can be given to teachers and implementers of educational transformations regarding the appropriateness and variety of techniques in teaching and learning sessions are necessary to ensure successful development of pupils. In fact, supporting Vygotsky's explanation of social constructivist theory that explaining scaffolding elements in projectbased learning strategies in teaching and learning sessions contributes to student achievement. Hence, this study was conducted to study the impact of PBL strategy by scaffolding on student achievement focusing on accounting principles for form 4 accounting students.

\section{Research Objective}

The objective of this research is to determine whether there are changes in MPEI PP performance through PBL strategy with scaffolding among the form four accounting students in private Religious Secondary School around Selangor. The hypotheses for this research are:

$\mathrm{H}_{01}$ : There is no significant difference for the mean score of pre-test between the students in the treatment group and control group.

$\mathrm{H}_{02}$ : There is no significant difference for the mean score of post-test between the students in the treatment group and control group.

$\mathrm{H}_{03}$ : There is no significant difference between pre-test and post-test mean score for students in the treatment group. 


\section{Methodology}

This research is carried out in one of private Religious Secondary School around Selangor within the period of four weeks by employing the quasi-experimental method that is incorporated with pre-test and post-test design on even number of control group. This research utilizes form 4 accounting students that studies MPEI PP as research sample. 40 students are involved in this research in which 20 students are placed in the treatment group while the other 20 students are placed in the control group.

Treatment group is the group that practices and receives PBL strategy with scaffolding while control group is the group that practices and receives PBL strategy traditionally which is through listening and writing method without scaffolding. Instrument used in this research is one set of pre-test questions and one set of post-test questions. Pretest is carried out in order to measure the students' level of knowledge, understanding, and memory of the two groups. Meanwhile, post-test is carried out to compare the scores that are achieved by both groups as well to evaluate the effectiveness of the teaching and learning strategy.

Data gathering process that is applied in this research involves four stages of execution; (1) 5 days before the treatment process, the respondents will receive explanation regarding project task execution and pre-test is given (2) All respondents are given four weeks (treatment duration) to ensure all the activities that are planned in both modules are clearly understood and the project is completed successfully (3) Post-test that has consistent content with pre-test is distributed to the students (4) The scores for both pretest and post-test are gathered and compared by using computerized statistic software 'IBM SPSS Statistics' to evaluate the changes that occurred within both groups before and after receiving treatment. Summarization of the data gathering process that is applied in this research is shown in Figure 2:

10 private Religious Secondary School around Selangor (Chosen Randomly - Fulfil Research Criteria)

One of 10 private Religious Secondary School around Selangor Chosen as a Sample

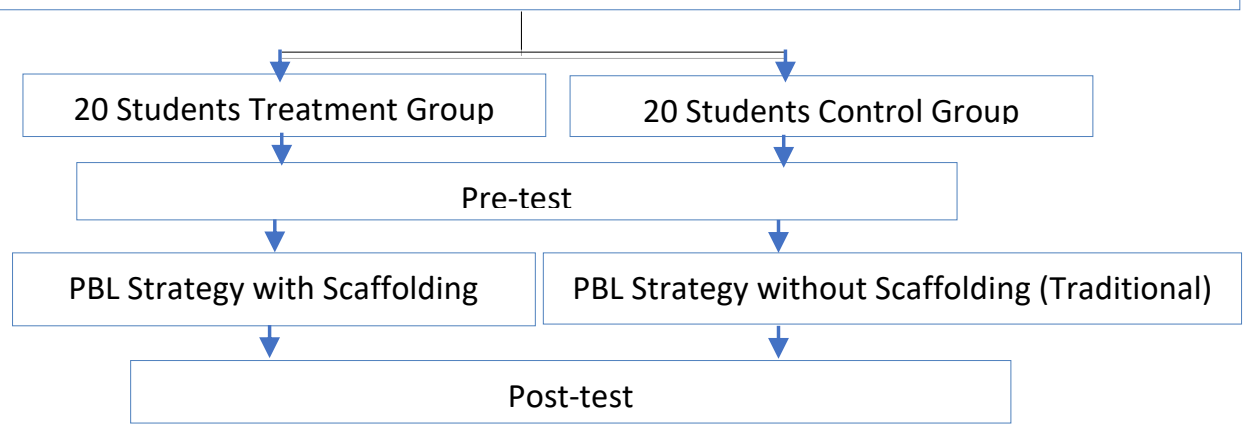

Figure 2: Research Gathering Process

\section{Findings}

$\mathrm{H}_{01}$ : There is no significant difference for the mean score of pre-test between the students in the treatment group and control group. 
Table 2: Grade/Marks Comparison for Pre-test between Treatment Group and Control Group

\begin{tabular}{lcccc}
\hline & \multicolumn{2}{c}{ Treatment Group } & \multicolumn{2}{c}{ Control Group } \\
Grade (Marks) & Frequency & Percentage (\%) & Frequency & Percentage (\%) \\
\hline C (50-54) & 6 & 30 & 3 & 15 \\
D (45-49) & 4 & 20 & 4 & 20 \\
E (40-44) & 7 & 35 & 7 & 35 \\
G (0-39) & 3 & 15 & 6 & 30 \\
\multicolumn{1}{c}{ Total } & 20 & 100 & 20 & 100 \\
\hline
\end{tabular}

Table 2 describes the findings for mark comparison acquired by the respondents from both treatment and control group. The highest grade achieved by both group is grade $C$ in which it is represented by $30 \%$ of the treatment group and $15 \%$ of the control group. The students that acquired grade $G$ are 3 students $(15 \%)$ in the treatment group and 6 students (30\%) in the control group.

Table 3: T-test Score for Pre-test on Treatment Group and Control Group

\begin{tabular}{lccccc}
\hline Variables & $M$ & $S D$ & $T$ & $d f$ & $p$ \\
\hline Pre-test Score & & & .044 & 38 & .965 \\
Treatment Group & 42.45 & 9.53 & & & \\
Control Group & 42.33 & 7.45 & & & \\
\hline
\end{tabular}

Table 3 shows the analysis of t-test score for pre-test on treatment group and control group. The findings indicate that there is no significant difference for mean value between treatment group $(M=42.45)$ and control group $(M=42.33)$. Therefore, $H_{01}$ is accepted which proves that the students' level of knowledge, understanding, and memory on the topic "Penyata Kewangan Milikan Tunggal" or "Financial Statement of the Sole Proprietorship" is even between treatment group and control group.

$\mathrm{H}_{02}$ : There is no significant difference for the mean score of post-test between the students in the treatment group and control group.

Table 4: Comparison of Grade/Marks for Post-test between Treatment Group and Control Group

\begin{tabular}{lcccc}
\hline & \multicolumn{2}{c}{ Treatment Group } & \multicolumn{2}{c}{ Control Group } \\
Grade (Marks) & Frequency & Percentage (\%) & Frequency & Percentage (\%) \\
\hline A (80-89) & 0 & 0 & 0 & 0 \\
A- (70-79) & 3 & 15 & 0 & 0 \\
B+ (65-69) & 0 & 0 & 1 & 5 \\
B (60-64) & 4 & 20 & 0 & 0 \\
C+ (55-59) & 4 & 20 & 1 & 5 \\
C (50-54) & 5 & 25 & 7 & 35 \\
D (45-49) & 2 & 10 & 3 & 15 \\
E (40-44) & 1 & 5 & 2 & 10 \\
G (0-39) & 1 & 5 & 6 & 30 \\
Total & 20 & 100 & 20 & 100 \\
\hline
\end{tabular}


Comparison of grade/marks for post-test between treatment group and control group is portrayed through Table 4 . The highest grade achieved by the students in the treatment group is $A-(15 \%)$. Meanwhile, the highest grade achieved by the students in the control group is $\mathrm{B}+(5 \%)$. The number of students that achieved grade $\mathrm{G}$ in the treatment group decrease during the post-test from $3(15 \%)$ students to $1(5 \%)$ student. As for control group, the students that acquired grade $\mathrm{G}$ maintains with a number of $6(30 \%)$ students.

Table 5: T-test Score for Post-Test on Treatment Group and Control Group

\begin{tabular}{lccccc}
\hline Variable & $M$ & $S D$ & $T$ & $d f$ & $p$ \\
\hline Post-test Score & & & 2.64 & 38 & .012 \\
Treatment Group & 54.99 & 11.35 & & & \\
Control Group & 46.52 & 8.78 & & & \\
\hline
\end{tabular}

Table 5 indicates the result of t-test for post-test on treatment group and control group. The finding shows that the mean value $(M=54.99)$ for treatment group is higher compared to the mean value $(M=46.52)$ for control group. This finding suggests that there is a significant difference in terms of mean value between treatment group and control group, $\mathrm{t}(38)=2.64, \mathrm{p}=.012$. Thus, $\mathrm{H}_{02}$ is rejected.

$\mathrm{H}_{03}$ : There is no significant difference between pre-test and post-test mean score for students in the treatment group

Table 6: Paired t-test Analysis for Results between Pre-test and Post -test on Treatment Group

\begin{tabular}{lccccc}
\hline Variable & $M$ & $S D$ & $T$ & $d f$ & $p$ \\
\hline Treatment Group & & & 14.43 & 19 & .000 \\
Pre-test & 42.45 & 9.53 & & & \\
Post-test & 54.99 & 11.35 & & & \\
\hline
\end{tabular}

T-test analysis for pre-test and post-test result on treatment group is shown in Table 6. The result shows that there is a significant difference in terms of mean score between pre-test and post-test, $t(19)=14.43, p=.000$. Therefore, $\mathrm{H}_{03}$ is rejected.

Overall, the researcher found that $\mathrm{H}_{01}$ was accepted while $\mathrm{H}_{02}$ and $\mathrm{H}_{03}$ were rejected. The conclusion was made according to the research finding in which there was a significant difference between mean values of pre-test and post-test on the treatment group. Thus, the result analysis proved the effectiveness of PBL with scaffolding compared to traditional way of PBL.

\section{Discussion}

Increase in level of knowledge, understanding and memory of the students could be observed on the treatment group. The treatment group are the respondents that apply and receive $\mathrm{PBL}$ with scaffolding strategy. The implementation of PBL with scaffolding strategy proved able to assist 20 students in mastering "Penyata Kewangan Milikan Tunggal" topic. Although the result showed one student was a little left behind and acquired grade $G$, there 
was still a high increase on the marks received by the student. In brief, there is increase in students' performance in mastering the topics learned.

Students that were exposed towards PBL with scaffolding strategy showed better performance compared to students that were exposed towards traditional PBL strategy. The number of students acquired grade $A$ - increased from 0 students to 3 students and the number of students that acquired grade $G$ decreased from 3 students to 1 student. This proved that PBL with scaffolding strategy was a success in helping the students enhancing their performance in mastering "Penyata Kewangan Milikan Tunggal" topic compared to traditional PBL strategy that does not involve scaffolding.

Referring to the third hypothesis $\left(\mathrm{H}_{03}\right)$, according to the analysis on the students' mark distribution, there was a significant increase in the number of students that achieved the highest score (70-79) and there was a significant decrease in the number of students that still lack the mastery (0-39) of "Penyata Kewangan MilikanTunggal" topic. The finding illustrates that scaffolding element in PBL strategy aid the students in enhancing their performance in mastering "Penyata Kewangan Milikan Tunggal" topic.

The result also supports and is supported by past researches that proved student mastery of a learned topic is the positive effect that is acquired through application of PBL with scaffolding strategy in teaching and learning session (See et al., 2015; Bell, 2010). Thus, this finding contributes toward knowledge in handling and helping weak students in learning as well as exposing a more effective learning strategy to the teachers that could be implemented in class.

\section{Conclusion}

Based on the findings and discussions presented, the findings prove that the use of PBL with scaffolding strategy, as compared to traditional PBL strategies, has a positive impact on students' level of knowledge, understanding, and memorize on the topic "Penyata Kewangan Milikan Tunggal" among Form 4 accounting students. This is evidenced by the findings of the study which show an increase in achievement for accounting principles subjects in treatment groups who have accepted and applied PBL with scaffolding strategy. Therefore, this PBL with scaffolding strategy is generally appropriate for teachers to apply in teaching and learning sessions to help contribute to the transformation of the student's mind while achieving excellence in learning.

However, there are obstacles in varying learning strategy as teachers lack in confidence on the effectiveness of PBL with scaffolding strategy (See et al., 2015), lack of resources and also time constraint during teaching and learning session (Salam et al., 2015). Therefore, it is suggested that more courses regarding varying learning strategy that are suitable to be implemented during teaching and learning strategy should be held. This is to ensure the teachers are prepared in realising the governments' wish to produce students that are balance intellectually, physically, emotionally, and spiritually as well as able to master the $21^{\text {st }}$ century skills (Mohamad Yusof, 2017).

Therefore, follow-up studies on the effectiveness of teaching and learning techniques and strategies that focus generally or specifically on specific subjects should be conducted to contribute to the findings of other strategies used in the teaching and learning session to ensure that students' mindset transformation worked. In fact, the findings of this follow-up study not only contribute to student excellence in learning, but also contribute to providing students with a high degree of marketability in themselves. 


\section{Acknowledgement}

The researchers also like to acknowledge the Ministry of Higher Education (MOHE) and University Putra Malaysia for the financial funding of this research through "Geran - Putra IPS" UPM (GP-IPS/2018/9608800), for Research University Grant (RUG).

\section{Corresponding Author}

Nor Sa'adah binti Jamaluddin

Faculty of Educational Studies,

Universiti Putra Malaysia.

Email: saadahjamaluddin86@gmail.com

\section{References}

Abosalem, Y. (2016). Assessment Techniques and Students' Higher-Order Thinking Skills. International Journal of Secondary Education, 4(1), 1-11.

Barak, M., \& Shachar, A. (2008). Project in Technology Education and Fostering Learning: The Potential and Its Realization. Journal Sciences Education Technology, 17: 285-296.

Bell, S. (2010). Project-Based Learning for the $21^{\text {st }}$ Century: Skills for the Future. The Clearing House. 83, 39-43.

Bowles, D., Radford, J., \& Bakopoulou, L. (2017). Scaffolding as a Key Role for Teaching Assistants: Perceptions of Their Pedagogical Strategies. British Journal of Educational Psychology, 2017.

Curriculum Development Department. (2016). Buku Penerangan Kurikulum Standard Sekolah Menengah (KSSM). Putrajaya: Kementerian Pendidikan Malaysia.

Curriculum Development Department. (2016). Dokumen Standard Kurikulum dan Pentaksiran (DSKP) Mata Pelajaran Prinsip Perakaunan. Putrajaya: Kementerian Pendidikan Malaysia.

Erdem, E. (2012). Examination of the Effects of Project Based Learning Approach on Students' Attitudes towards Chemistry and Test Anxiety. World Applied Sciences Journal, 17 (6), 764-769.

Frank, M., \& Barzilai, A. (2004). Integrating Alternative Assessment in A Project-Based Learning Course for Pre-Service Science and Technology Teachers. Assessment \& Evaluation in Higher Education, 29 (1), 41-61.

Guthrie, C. (2008). Towards Greater Learner Control: Web Supported Project-Based Learning. Journal of Information Systems, 21(1): 121-131.

Ismail, M. Z., \& Othman, M. K. (2017). Amalan Pedagogi Abad Ke-21 dalam Kalangan Guru Pelatih Program ljazah Sarjana Muda Perguruan (PISMP) Pendidikan Islam di Institut Pendidikan Guru Malaysia. Jurnal Penyelidikan Dedikasi, Jilid 13.

Kizkapan, O., \& Bektas, O. (2017). The Effect of Project Based Learning on Seventh Grade Students' Academic Achievement. International Journal of Instruction, Vol. 10, No.1.

Mcleod, S. A. (2007). Simply Psychology: Vygotsky (online). http://www.simplypsychology.org/cognitive.htm. Accessed on Sept, 15, 2018.

Mohamad Yusof, K. (2017). Laporan Tahunan 2016 (Pelan Pembangunan Pendidikan Malaysia 2013-2025). Putrajaya: Kementerian Pendidikan Malaysia. Retrieved from http://www.moe.gov.my.

Arshad, M. A. Y., \& Yasin, M. R. (2015). Kemahiran Berfikir Aras Tinggi murid dalam Konteks Penyelesaian Masalah bagi Mata Pelajaran Sains. Asian Education Action Research 
Journal, 4, 81-96.

Moursund, D. (1999). Project- Based Learning Using Information Technology. International Society for Technology in Education. http://i-a-e.org/downloads/free-ebooks-by-davemoursund.html.

Nooriza, K., \& Effandi, Z. (2015). Integrasi Kemahiran Berfikir Aras Tinggi dalam Pengajaran dan Pembelajaran Matematik: Analisis Keperluan Guru. Conference: Prosiding Seminar Education Graduate Regional Conference (EGRC 2015).

Nordin, A. B. (2013). Kurikulum ke Arah Penghasilan Kemahiran Berfikiran Kritis, Kreatif dan Inovatif. Jurnal Kurikulum \& Pengajaran Asia Pasifik, Bil 1, Isu 1.

Othman, Y., \& Osman, S. (2014). Keupayaan Menguasai Kemahiran Menulis Melalui Pembelajaran Berasaskan Projek dalam Penulisan Berbentuk Risalah di Sekolah Rendah. Jurnal Pendidikan Bahasa Melayu, Vol. 4, Bil. 1, ms 19-29.

Robinson, J. (2013). Project-Based Learning: Improving Student Engagement and Performance in the Laboratory. Analytical \& Bioanalytical Chemistry, 405 (1): 7-13. doi: 10.1007/s00216-012-6473-x.

Roy, H. (2018): Doing, Being, and Becoming: A Historical Appraisal of the Modalities of Project-Based Learning. Teaching in Higher Education, DOI: 10.1080/13562517.2017.1421628

Salam, F., Mailok, R., \& Ubaidullah, N. (2015). Perubahan Pencapaian Mata Pelajaran Teknologi Maklumat dan Komunikasi melalui Pembelajaran Berasaskan Projek dengan Scaffolding. Jurnal Pendidikan Malaysia, 40 (1), 29-41.

See, Y. G., Rashid, M. A., \& Bakar, Ab. R., (2015). The Effect of Project Based Learning on Level of Content Knowledge of Pre-Vocational Subject. Mediterranean Journal of Social Sciences, Vol 6, No 6. S4.

Vygotsky, L. S. (1978). Mind in Society - The Development of Higher Psychological Processes. Cambridge: Harvard University Press.

Wilkin, C. L. (2017). Enhancing Critical Thinking: Accounting Students' Perceptions. Education + Training, 59 (1), 15-30. https://doi.org/10.1108/ET-01-2015-0007.

Wood, D., Bruner, J. S., \& Ross, G. (1976). The Role of Tutoring in Problem Solving. Journal of Child Psychology \& Psychiatry \& Allied Disciplines, 17 (2): 89-100. doi: 10.1111/14697610. 